"An evaluation of the links between quality of reporting and efficiency of investment in companies listed at Tehran Stock Exchange"

\begin{tabular}{|c|c|c|}
\hline AUTHORS & \multicolumn{2}{|l|}{$\begin{array}{l}\text { Keyvan Hayati } \\
\text { Parastoo Sedaghat }\end{array}$} \\
\hline ARTICLE INFO & \multicolumn{2}{|c|}{$\begin{array}{l}\text { Keyvan Hayati and Parastoo Sedaghat (2016). An evaluation of the links } \\
\text { between quality of reporting and efficiency of investment in companies listed at } \\
\text { Tehran Stock Exchange. Problems and Perspectives in Management, 14(3-si), } \\
\text { 341-347. doi:10.21511/ppm.14(3-si).2016.06 }\end{array}$} \\
\hline DOI & \multicolumn{2}{|c|}{ http://dx.doi.org/10.21511/ppm.14(3-si).2016.06 } \\
\hline RELEASED ON & \multicolumn{2}{|l|}{ Thursday, 15 September 2016} \\
\hline JOURNAL & \multicolumn{2}{|c|}{ "Problems and Perspectives in Management" } \\
\hline FOUNDER & \multicolumn{2}{|c|}{ LLC "Consulting Publishing Company "Business Perspectives" } \\
\hline$\sigma^{\circ}$ & 15 & モニこ \\
\hline NUMBER OF REFERENCES & NUMBER OF FIGURES & NUMBER OF TABLES \\
\hline 0 & 0 & 0 \\
\hline
\end{tabular}

(c) The author(s) 2023. This publication is an open access article. 
Keyvan Hayati (Iran), Parastoo Sedaghat (Iran)

\title{
An evaluation of the links between quality of reporting and efficiency of investment in companies listed at Tehran Stock Exchange
}

\begin{abstract}
This paper aims to evaluate the relationship between the quality of reporting and efficiency of investment in companies registered at Tehran Stock Exchange Market during 2010-2014 (Iranian calendar) period. The population consists of manufacturing firms registered at Tehran Stock Exchange and the statistical sample includes 126 companies. To explore the assumptions of the research, secondary data, as well as audited balance sheets have been used to collect the data. The data have been analyzed using descriptive and inferential methods at two levels and via Panel Yapold tests. Reliability for variables has been verified using Luin, Leen and Chu methods for data related to the study. The results coming out of the study have been obtained by financial and monetary data of the companies registered at Tehran Stock Exchange during the years between 2010 and 2014 and have been analyzed. It was illustrated that not only companies that used higher qualities of reporting had better investments, but also the higher quality of reporting itself made the investments more efficient. Moreover, the results showed that there is negative and significant relation between too much investment and quality of financial reporting and between too little investment and the quality of reporting.
\end{abstract}

Keywords: quality of reporting, investment efficiency, Tehran Stock Exchange.

JEL Classification: M41, M42, G32.

\section{Introduction}

Investment carried out by companies has always been considered as a means to develop and prevent recession and burnout in various matters. According to the developments and turn of events in the modern world and especially in the developing countries which are struggling with ample problems, the countries need proper and practical solutions to further use the Godgiven properties and wealth that are inherent in every country. In so doing, one of the important methods is to extend and develop investment (Tehrani \& Noorbakhsh, 2006). This is while the limitations and constraints in sources have contributed to the fact that the efficiency of investment has more importance than developing and furthering the investment process. Generally speaking, investment efficiency means the acceptance of projects with net worth being positive at the current time and inefficiency means the selection of projects with current negative net value (too much investment) or not choosing the opportunities if investment. Monetary reports are among available means to obtain information that are expected to bring about investment both in the increase of efficiency and development (Hubbard, 1998).

Monetary reports are anticipated to provide the following: necessary information to evaluate the financial situation and power of the enterprise, evaluation of functions and potential to bring about profitability, exploring ways of financial budget preparation, evaluation of how to be a good consultant

(C) Keyvan Hayati, Parastoo Sedaghat, 2016.

Keyvan Hayati, M.A. in Financial Management, Department of Management, Sanandaj Branch, Islamic Azad University, Sanandaj, Iran.

Parastoo Sedaghat, Assistant Professor, Department of Management, University of Kurdistan, Sanandaj, Iran. and doing legal tasks, providing supplementary information to better understand financial information and to predict future moves to some extent. Hence, the reports are especially important in the aforementioned goals coming true and an increase in their quality can lead to more efficient investments and maintaining, as well as developing the resources (Chaney, Sraer \& Thesmar, 2012).

One of the elements of efficient markets is producing quality reports and publishing them for people who have stakes in the business. The quality of information that is going to be available to users has impacts on the decisions. This is why the quality of the provided data is so important to companies. On the other hand, the resources that are available to companies are interesting to investors and the type of return that these have are to reaching the goals of the investors. Financial budget resources according to the necessity of the information and the feasibility studies for the investments have great influence on the quality of investment and reporting. The evaluation of the relations between reporting and efficiency of investment is the focal point for researchers, but there has been little, if any focus on the impacts of the type of financial providing on the quality of reporting and consequently the investment of the company. Regarding the fact that in the recent years, as well as future years, financial budget is considered to be important as a challenge in companies, this topic is analyzed in the paper too.

The quality of financial reports is defined as the power of financial statements to transfer the operational information of the company and specifically to predict the cash flow for the investors. According to this view, because accruals improve on the value of benefits 
through diminishing the impacts of unstable fluctuations in cash flows (Dechow \& Dichev, 2002), in this paper, the quality of accruals for working capital has been considered as an alternative to financial reporting. Regarding the fact that the effect of accounting information on capital markets is evident, the effects have great influence on the efficiency of investment. The studies carried out by researchers such as Kyle (1985) and Admati (1985) are in fact the pioneers of the studies that ignited the start of effects of accounting quality on efficiency of investment. The researchers showed that efficiency of investment is influenced by methods of financial reporting that could be influential on stock market (assuming that market could be efficient or semi-efficient).

Regarding the information put forward in this matter, we intend to find out how much quality of reporting is influential upon the efficiency of investment in companies registered at Tehran Stock Exchange market. The main purpose is to determine the influence of financial supply methods on investment.

\section{Assumptions to the study}

Main assumption: There is a significant relation between the quality of financial reporting and the efficiency of investment in firms registered at Tehran Stock Exchange.

Marginal assumptions:

1. There is a significant relation between quality of reporting and efficiency of investments (too much) in firms registered at Tehran Stock Exchange.

2. There is a significant relation between the quality of reports and the efficiency of low investment activities in firms registered at Tehran Stock Exchange.

\section{Theoretical framework and literature}

2.1. Financial reporting quality. The quality of reporting quality is defined as precision and correctness of financial reports in stating the information related to the company operations especially the cash flow trend to fully inform the investors. According to the concept statement No.1 of standard committee, financial reporting should provide proper information to help potential investors to decide upon the financial situation. Moreover, according to statement No. 2 of committee, standard financial reports provide information that help investors to evaluate the costs, timing and uncertainty of cash flow in future risks. Hence, the quality of accruals is used as a touch stone to evaluate the quality of financial reports (Tehrani \& Noorbakhsh, 2006). According to this view that accruals improve the value of benefits with decreasing the effects of unstable fluctuations in cash flow trend, accruals estimate the cash flows and future earnings (Verdi, 2006).
The power of financial statements in transferring information of operational type activities of the company and specifically predicting the cash flow that is expected to investors according to the view that accruals improve on the value of benefits with sagging the effects of unstable fluctuations in cash flow trend (Dechow \& Dichev, 2002), in this paper, the quality of working capital accruals is regarded as an alternative to financial reports quality. Currently, one of the main aims of reporting is providing useful information for deciding and information and intelligence systems of accounting play important roles in progressing the aims of the organization, as well as the total economy of this collapsed country in terms of economic situation. Bushman and Smith (2001) have summarized the role of reports in influencing the economic situation in three aspects: accounting information can be used to determine the being good or bad of projects by investors. The high quality of accounting information can be used as a control mechanism to help managers to decide in favor of profitable projects and keep away from bad projects that carry loss. Finally, financial reporting can decrease the asymmetrical values of information and decrease the costs for stakeholders.

2.2. The role of reports. The quality of reports can be related to investment efficiency in two ways at least:

1. Financial reports decrease the costs of not proper selection between the company and stakeholders and between stakeholders themselves (Verrecchia, 2001).

2. Financial reporting can be highly influential in decreasing the problems of brokerage. Hence, the information of financial accounting in stock market can have supervising roles in the market as the main source of information. Thus, if the quality of reporting decreases the problems of brokerage, it truly can increase the efficiency of investment via the increasing ability of shareholders in controlling the managers (Bushman \& Smith, 2001).

The results of Verdi's studies (2006) show that the index of quality of financial reporting that is named the quality of accruals has correlation to low investment and highly aggregated investment in negative ways. The relations between the quality of reporting and low investment ventures is stronger for companies that struggle with limits of money and fund raising. This is with inference that accounting information can decrease the asymmetry between investor's information and that of the company. Moreover, the relation between quality of financial reporting and too high investment is stronger for companies with higher cash remains. The quality of financial reporting can decrease the asymmetry of information between mother company and its affiliates and decreases the 
costs of shareholders for supervising managers and optimizing the selection of better projects. About companies that have weaker intelligence processes, the relation between the quality of financial reporting and efficiency of investment is stronger (ibid).

2.3. Investment efficiency. Investment is defined as turning money into one or various types of properties that will be kept for a while in the future. The investment of money in different properties is only one part of business planning that many people are interested in. Before investments are made, everybody should prepare a total monetary plan. Such plan should consist of decisions related to the contract. Moreover, regarding the type of ownership, lifetime of property, the rates of profitability, etc., decisions should be made. Finally, the plan should provide the necessary minimum amount of investment (Diamond, 1985).

2.4. Investment efficiency (low investment). The negative deviation value from the expected investment. In other words, investing with less amounts that are expected is regarded as low investment.

2.5. Investment efficiency (over-investment). This term is used when positive deviation is made from expected investment. In other words, investment amounts that are more than expected and anticipated investment rates is over investment (Modarres \& Hesarzadeh, 2008).

Mahmoodabadi, Rezaei \& Gorgani Firozjah (2014) in a paper dealt with the effects of intellectual property in optimizing the quality of reporting in companies registered at Tehran Stock Exchange market. From Francis et al. model (2005), the quality of accruals as an indicator for the quality of reporting and from Pulic's model in 2000, for evaluation of intellectual property were used. The population to this research consists of 76 firms registered at Tehran Exchange market that were analyzed in the period between 20032009. The results of assumption tests show that there is a direct significant relation between structural capital efficiency coefficient and that of human capital. However, the relation between physical capital efficiency coefficient and quality of financial reporting was found to be statistically insignificant.

Badavar and Taghizadeh (2013) in their paper evaluated the relation between the quality of auditing and efficiency of investment in companies registered at Tehran Exchange market. 100 companies were selected as sample for the 2006-2011 period. The results show that generally there is a positive and significant relation between quality of auditing and investment efficiency. Hence, increasing and optimizing the quality of auditing with eliminating the asymmetry of information between managers and investors and eliminating the problems of delegation leads to better efficiency of investment.
Darabi and Salmani (2014) in 2013 in their paper entitled the relations between efficiency of intellectual property and quality of reporting showed that there is a positive significant relation between human property efficiency and that of physical property and quality of financial reporting.

Bae and Choi (2012) evaluated the relations between skills of auditors and efficiency of investment among service-offering companies. Using a big sample of Korean firms in the period of 1976-2005, they showed that skills of auditors in industries have positive relations with investment efficiency.

Chen et al. (2010) evaluated the relation between quality of financial reporting and investment efficiency in privately-owned companies of developing markets. They analyzed the data from 79 countries in 2002 . The results show that quality for fiscal year of 2005 is positively correlated to efficiency of investment. Moreover, financial supply for the companies through banks leads to optimum role of accounting intelligence in investing decision making and decreases the motive to minimize the benefit for tax evasion.

\section{Conceptual model to the research}

In this model, to evaluate the relation between the quality of reporting and investment efficiency, the proposed model by Chen et al. (2010) was used. The logic behind the formation of this framework is built upon the concept of relation between quality of reporting and efficiency of investment. As you will see in the conceptual model diagram at the right, dependent variable (investment efficiency) is shown and at the left independent variable (quality of accrual reporting) is depicted.

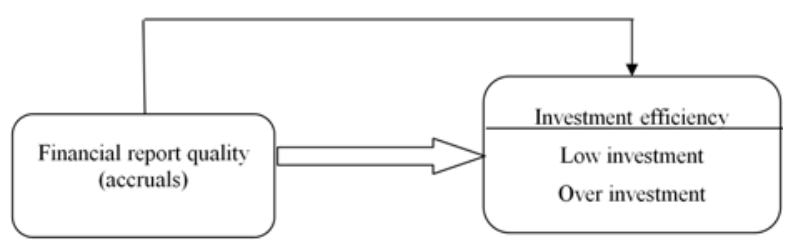

Fig. 1. Conceptual model

Source: Chen at al. (2010).

\section{Research methodology}

This paper is applied type in the sense of purpose. Moreover, regarding the nature of this topic, this research is descriptive and correlational as far as methodology is concerned. This is why it aims to evaluate the relations between variables. The population includes all the companies registered at Tehran Stock market during the 2010-2014 period. The sampling method used is systematic elimination (screening). The sampling was carried out elimination methods. The companies that are members in any industry should have the following terms: 
1. Their fiscal period should end in 20 March $\left(29^{\text {th }}\right.$ Esfand Hijri).

2. Every company should have enough data in all the years 2010-2014 meaning it should be active in all the period in Tehran Stock Exchange.

3. Every company in every year should be studied at least 9 times in a year.

4. It should not be included in intermediary companies such as investment ventures and banks.

5. It should not be a holding, since their nature is different from other members.

6. The company should not have changed its fiscal year during 2010-2014 period.

Table1. Sampling methods according to the aforementioned constraints

\begin{tabular}{|l|c|}
\hline \multicolumn{1}{|c|}{ Constraints } & Companies \\
\hline $\begin{array}{l}\text { Companies registered at Tehran Stock Exchange until the end of } \\
1393\end{array}$ & 496 \\
\hline Companies that end of their fiscal year is not Esfand & 93 \\
\hline Banks, insurnace and intermediary companies & 36 \\
\hline Not included in the realm of Holding Co. & 22 \\
\hline $\begin{array}{l}\text { Companies which had 3 months of interval form work and whose } \\
\text { information regarding price of selling was not available }\end{array}$ & 95 \\
\hline $\begin{array}{l}\text { Companies whose information has been eliminated from Stock } \\
\text { Market }\end{array}$ & 89 \\
\hline $\begin{array}{l}\text { Companies which had changed the fiscal year in the period of } \\
\text { research }\end{array}$ & 35 \\
\hline Remaining firms in the sample & 126 \\
\hline
\end{tabular}

According to the aforementioned criteria, 126 firms were selected. Subsequently, all the data needed for the research were collected from databases of Tehran Stock Exchange, Rahavard Novin, Tadbir Pardaz software, and Stock journals.

To test the assumptions, Pearson correlation coefficient and mono- and multi-variable regression analysis were used for the research. Moreover, data analysis was carried out using Eviews version 7. To determine population distribution, that is being normal or abnormal, Kolmogorov-Smirnov tests have been done. The assumptions to this study are as follows:

\section{Findings}

According to table of the aforementioned tests, if the levels of being significant are higher than test level $(0.05)$ for all the variables, data distribution is deemed to be normal.

Table 2. Kolmogorov-Smirnov test for variables

\begin{tabular}{|l|c|c|c|l|}
\hline \multicolumn{1}{|c|}{ Cause } & $\begin{array}{c}\text { Sig. } \\
\text { Level }\end{array}$ & $\begin{array}{c}\text { Error } \\
\text { Value }\end{array}$ & $\begin{array}{c}\text { Assumption } \\
\text { Verification }\end{array}$ & Conclusion \\
\hline $\begin{array}{l}\text { Quality of financial } \\
\text { reporting, optional } \\
\text { accruals }\end{array}$ & $0 / 125$ & $0 / 05$ & $\mathrm{H}_{0}$ & Normal \\
\hline Property yield & $0 / 253$ & $0 / 05$ & $\mathrm{H}_{0}$ & Normal \\
\hline Growth opportunity & $0 / 314$ & $0 / 05$ & $\mathrm{H}_{0}$ & Normal \\
\hline Physical asset & $0 / 421$ & $0 / 05$ & $\mathrm{H}_{0}$ & Normal \\
\hline $\begin{array}{l}\text { Cash flow to physical } \\
\text { asset ratio }\end{array}$ & $0 / 259$ & $0 / 05$ & $\mathrm{H}_{0}$ & Normal \\
\hline
\end{tabular}

Source: results of the study.

According to the results obtained from the above table, since significance level value for all the components is higher than the error of 0.05 , the variables have normal distribution, hence, we use parametric tests to analyze the assumptions.

We use Levin, Leen, and Choi tests to calculate the reliability. The results of the study show that both dependent and independent variables have been reliable during the study. The reason is because $p$ value has been less than 5 percent for the test.

Table 3. Reliability test for variables

\begin{tabular}{|l|c|c|}
\hline \multicolumn{1}{|c|}{ Variables } & $\begin{array}{c}\text { Levin, Leen, Choi } \\
\text { statistic value }\end{array}$ & $\begin{array}{c}\text { Levin, Leen, Choi } \\
\text { statistics chance }\end{array}$ \\
\hline $\begin{array}{l}\text { Quality of financial reporting, } \\
\text { optional accruals }\end{array}$ & $-24 / 33$ & $0 / 0000$ \\
\hline Property yield & $-52 / 32$ & $0 / 0000$ \\
\hline Growth opportunity & $-42 / 31$ & $0 / 0000$ \\
\hline Physical asset & $-39 / 21$ & $0 / 0000$ \\
\hline Cash flow to physical asset ratio & $-51 / 30$ & $0 / 0000$ \\
\hline
\end{tabular}

Note: research assumption tests.

Main assumption: There is a significant relation between the quality of financial reporting and investment efficiency in companies registered at Tehran Stock Exchange market.

Table 4. The results for model evaluation for the main assumption

\begin{tabular}{|c|c|c|c|c|}
\hline \multirow{2}{*}{ Variable name } & \multirow{2}{*}{ Sig. } & \multicolumn{3}{|c|}{ Dependent variable: investment efficiency } \\
\hline & & Coefficient & T Statistic & $P$-value \\
\hline Constant value & C & $-0 / 037$ & $-195 / 036$ & $0 / 000$ \\
\hline Quality of reports (optional accruals) & TACCR & $0 / 602$ & $4 / 016$ & $0 / 014$ \\
\hline Asset efficiency & $\mathrm{ROA}$ & $0 / 510$ & $3 / 892$ & $0 / 032$ \\
\hline Growth opportunity & GO & $0 / 492$ & $0 / 429$ & $0 / 667$ \\
\hline Tangible assets & FA & $-0 / 001$ & $-1 / 691$ & $0 / 091$ \\
\hline Cash flow to constant physical asset ratio & CFOFA & $-1 / 075$ & $-0 / 236$ & $0 / 813$ \\
\hline \multicolumn{2}{|l|}{$\mathrm{R}^{2}$} & \multicolumn{3}{|c|}{$0 / 769$} \\
\hline \multicolumn{2}{|l|}{$\mathrm{R}^{2}$ balanced } & \multicolumn{3}{|c|}{$0 / 724$} \\
\hline \multicolumn{2}{|l|}{ Durbin-Watson } & \multicolumn{3}{|c|}{$1 / 753$} \\
\hline \multicolumn{2}{|l|}{ F statistic } & \multicolumn{3}{|c|}{$48003 / 82$} \\
\hline \multicolumn{2}{|l|}{ P-value } & \multicolumn{3}{|c|}{$0 / 000$} \\
\hline
\end{tabular}


There is a significant relation between effects of quality of reporting and investment efficiency (0.602) regarding the chance of $t$ statistic (0.014). This shows the fact that there is certainly a positive and significant relation between quality of reporting and investment efficiency. The first marginal assumption: there is a significant relation between quality of over investment and reporting quality in companies registered at Tehran Stock Exchange.
Combined regression model for constant effects of reporting quality on investment efficiency for over-investment is negative (-0.610) and, according to the value of $\mathrm{T}$ statistic, chance $(0.000)$ is significant. This shows that reporting quality has negative impacts on over-investment efficiency. Regarding the significance of this relation, this is a safe bet that the first assumption is not flouted and hence is verified.

Table 5. The results of model evaluation for the first assumption

\begin{tabular}{|c|c|c|c|c|}
\hline \multirow{2}{*}{ Variable type } & \multirow{2}{*}{ Sig. } & \multicolumn{3}{|c|}{ Dependent variable: investment efficiency } \\
\hline & & Coefficient & T Statistic & P-value \\
\hline Fixed value & C & $-0 / 294$ & $-1073 / 275$ & $0 / 000$ \\
\hline Quality of reporting (optional accruals) & TACCR & $-0 / 610$ & $-5 / 948$ & $0 / 000$ \\
\hline Asset yield & ROA & $0 / 286$ & $3 / 043$ & $0 / 005$ \\
\hline Growth opportunities & GO & $0 / 192$ & $1 / 341$ & 0/018 \\
\hline Fixed physical asset & FA & $0 / 000$ & $-0 / 393$ & $0 / 693$ \\
\hline Cash flow to fixed physical asset ratio & CFOFA & $0 / 934$ & $0 / 197$ & $0 / 843$ \\
\hline$R^{2}$ & & \multicolumn{3}{|c|}{$0 / 649$} \\
\hline $\mathrm{R}^{2}$ balanced & & \multicolumn{3}{|c|}{$0 / 639$} \\
\hline Durbin-Watson & & \multicolumn{3}{|c|}{$1 / 737$} \\
\hline F statistic & & \multicolumn{3}{|c|}{ 19441/64 } \\
\hline P-value & & \multicolumn{3}{|c|}{$0 / 000$} \\
\hline
\end{tabular}

Second marginal assumption: There is a significant relation between the quality of reporting and efficiency of low investment in companies registered at Tehran Stock Exchange market.

Combined regression model for fixed impacts of reporting quality on the efficiency of investment (low investment) is negative (-0.309) and regarding the chance of $t$ statistic $(0.003)$ is significant). This shows that the quality of reporting has negative significant relation with efficiency of low investment. Hence, the second assumption is verified too.

Table 6. Results of model evaluation for the second assumption

\begin{tabular}{|c|c|c|c|c|}
\hline \multirow{2}{*}{ Variable type } & \multirow{2}{*}{ Sig. } & \multicolumn{3}{|c|}{ Dependent variable: investment efficiency } \\
\hline & & Coefficient & T Statistic & P-value \\
\hline Fixed value & C & $1 / 057$ & $55 / 673$ & $0 / 000$ \\
\hline Quality of for fixed optional accruals & TACCR & $-0 / 309$ & $-4 / 077$ & 0/003 \\
\hline Asset yield & ROA & $-0 / 200$ & $-3 / 108$ & $0 / 019$ \\
\hline Growth opportunities & GO & $-6 / 25$ & $-0 / 271$ & $0 / 786$ \\
\hline Fixed physical asset & $\mathrm{FA}$ & $-0 / 002$ & $-1 / 661$ & 0/098 \\
\hline Cash flow to tangible assets rati & CFOFA & $-1 / 93$ & $-0 / 287$ & $0 / 774$ \\
\hline $\mathrm{R}^{2}$ & & \multicolumn{3}{|c|}{$0 / 689$} \\
\hline $\mathrm{R}^{2}$ balanced & & \multicolumn{3}{|c|}{$0 / 674$} \\
\hline Durbin-Watson & & \multicolumn{3}{|c|}{$1 / 804$} \\
\hline F statistic & & \multicolumn{3}{|c|}{$7419 / 473$} \\
\hline P-value & & \multicolumn{3}{|c|}{$0 / 000$} \\
\hline
\end{tabular}

\section{Conclusion and discussion}

According to the results of Pearson's correlation coefficient test and regression, distribution proved the significance of correlation and regression according to the significance levels. Hence, we can say there is a significant relation between quality of company's reporting and investment efficiency. The results obtained from the main assumption show that with an increase in quality of reporting, over investment and low investment decrease and, hence, the efficiency of investment is in total terms increased. Hence, with theoretical findings of the research and studies done by Francis et al. (2005), Biddel and Hilary (2006), Verdi (2006), Biddle, Hilary \& Verdi (2009), Lee et al. (2009) and Chen et al. (2010) outside of Iran and within Iran studies by Modarres and Hesarzadeh (2008) are supportive to this research.

Bearing in mind the significant negative relation between quality of financial reporting and investment efficiency (over-investment), the first assumption is, 
thus, verified. With the verification of the second assumption, we reached the conclusion that quality of financial reporting is an influential factor in a reduction in over investment and the more the quality of accounting reporting the less the risky over investment in firms. Moreover, the more the companies can make profit of the assets, the faster they submit their reports and, thus, the investment efficiency increases. This finding is mush similar to that of research works such as Al-ajmi (2008), Dogan, Coskun \& Celik (2007), Leventisa \& Weetmanb (2004), Bagnoli et al. (2002) to name but a few who have done research outside of Iran, and Qayyumi (2011) and Badavar Nahandi (2009) in Iran.

Regarding the significance of negative relation of quality of reporting on low investment efficiency, the second assumption is not flouted in fact is totally verified. In this paper, control variables include: asset efficiency, growth opportunities, physical assets, cash flow to tangible assets ratio among which only asset efficiency variable had significant relation with investment yield. The results obtained from this research is supportive of that of Biddle, Hilary \& Verdi (2009), and Verdi (2006).

This paper aims to evaluate the relation between quality of reporting and investment efficiency. The results coming out of companies registered at Tehran Stock Exchange showed that companies that had higher quality of reporting had better investment and better quality of reporting per se causes better investment. Moreover, it was revealed in this paper that there is a negative significant relation between quality of reporting and over investment, as well as low investment. Generally speaking, it was revealed that we can optimize the efficiency of investment with making a balance in the two extremes of over investment and low investment. Provided information and principles in this research can be raw data for future researchers of the field to use fully. The fundamental underpinning information used in this paper show that quality of monetary reporting contributes to such important breakthroughs as increase in cash flow, decrease of costs for asset taxes, and increase of the company's growth rate. This finding is in line and supportive of the results of the study done by Gomariz \& Ballesta (2014).

\section{Suggestions and limitations}

The results of this study can urge accounting professionals to provide better information to fully meet the needs of society and urge the users of accounting information to pay special attention to how the information is obtained. We hereby suggest managers at Tehran Stock Exchange to have more serious supervision to reduce the asymmetry of investment activities.

Auditing institutions as the other powerful body that supervises the activities in the market should guarantee the quality of the reports via increasing the quality of monetary auditing. They ought to do their tasks regarding credit giving for these documents.

The lack of rating bodies and institutions in Iran, turning fund raising to a favoritism activity in Iran, to collect data, we used a sample of companies and financial statements and such factors as redundancy and some articles in the terms of accounting reports like influential factors statements were eliminated. Due to unavailability of needed information in this research, no balance was made for the items. Other constraints and limitations include problems with laws and principles that are in force in Iran especially regulations related to direct income taxes.

\section{References}

1. Admati, A.R. (1985). A Noisy Rational Expectations Equilibrium for Multi-Asset Securities Markets, Econometrica, 53 (3), pp. 629-658. doi:10.2307/1911659.

2. Al-Ajmi, J. (2008). Audit and Reporting Delays: Evidence from an Emerging Market, Advances in Accounting, 24 (2), pp. 217-226. doi:10.1016/j.adiac.2008.08.002.

3. Badavar Nahandi, Y. (2009). Explain and Provide a Model for Identifying and Assessing the Factors Affecting the Quality of Financial Reporting in Iran. (PhD Thesis). Islamic Azad University, Science and Research Branch of Tehran.

4. Badavar Nahandi, Y. \& Taghizadeh Khanqah, V. (2013). The Relationship between Audit Quality and Investment Efficiency, The Iranian Accounting and Auditing Review, 20 (2), pp. 19-42. Available at: https://acctgrev.ut.ac.ir/article_35523.html.

5. Bae, G. \& Choi, S. (2012). Do Industry Specialist Auditors Improve Investment Efficiency? Social Science Electronic Publishing, 46 p. doi:10.2139/ssrn.2145191.

6. Bagnoli, M., Kross, W. \& Watts, S.G. (2002). The Information in Management's Expected Earnings, Journal of Accounting Research, 40 (5), pp. 1275-1296. doi:10.1111/1475-679X.t01-1-00054.

7. Biddle, G. \& Hilary, G. (2006). Accounting Quality and Firm-Level Capital Investment, The Accounting Review, 81 (5), pp. 963-982. Available at: http://www.jstor.org/stable/4093094.

8. Biddle, G., Hilary, G. \& Verdi, R. (2009). How does Financial Reporting Quality Relate to Investment Efficiency? Journal of Accounting and Economics, 48 (2-3), pp. 112-131. doi:10.1016/j.jacceco.2009.09.001.

9. Bushman, R. \& Smith, A. (2001). Financial Accounting Information and Corporate Governance, Journal of Accounting and Economics, 32 (1-3), pp. 237-333. doi:10.1016/S0165-4101(01)00027-1.

10. Chaney, T., Sraer, D. \& Thesmar, D. (2012). The Collateral Channel: How Real Estate Shocks Affect Corporate 
Investment, American Economic Review, 102 (6), pp. 2381-2409. doi:10.1257/aer.102.6.2381.

11. Chen, F., Hope, O.-K., Li, Q. \& Wang, X. (2010). Financial Reporting Quality and Investment Efficiency of Private Firms in Emerging Markets, Social Science Electronic Publishing, 55 p. doi:10.2139/ssrn.1635425.

12. Darabi, R. \& Salmani, K. (2014). The Relationship of Disclose of Intcapital Components on Financial Reporting Quality. Master's Thesis. Allameh Tabatabaei University.

13. Dechow, P.M. \& Dichev, I.D. (2002). The Quality of Accruals and Earnings: The Role of Accrual Estimation Errors, The Aaccounting Review, 77 (s-1), pp. 35-59. Available at: http://www.aaajournals.org/doi/abs/10.2308/accr.2002.77.s-1.35.

14. Diamond, D. (1985). Optimal Release of Information By Firms, The Journal of Finance, 40 (4), pp. 1071-1094. doi:10.1111/j.1540-6261.1985.tb02364.x.

15. Dogan, M., Coskun, E. \& Celik, O. (2007). Is Timing of Financial Reporting Related to Firm Performance? An Examination on ISE Listed Companies, International Research Journal of Finance and Economics, 12, pp. 220-233. Available at: http://www.internationalresearchjournaloffinanceandeconomics.com/ISSUES/irjfe_12_15.pdf.

16. Francis, J., LaFond, R., Olsson, P. \& Schipper, K. (2005). The Market Pricing of Accruals Quality, Journal of Accounting and Economics, 39 (2), pp. 295-327. doi:10.1016/j.jacceco.2004.06.003.

17. Gomariz, M. \& Ballesta, J. (2014). Financial Reporting Quality, Debt Maturity and Investment Efficiency, Journal of Banking \& Finance, 40, pp. 494-506. doi:10.1016/j.jbankfin.2013.07.013.

18. Hubbard, R. (1998). Capital-Market Imperfections and Investment, Journal of Economic Literature, 36 (1), pp. 193-225. doi:10.3386/w5996

19. Kyle, A. (1985). Continuous Auctions and Insider Trading, Econometrica, 53 (6), pp. 1315-1335. doi: $10.2307 / 1913210$

20. Lee, G. \& Masulis, R.W. (2009). Seasoned Equity Offerings: Quality of Accounting Information and Expected Flotation Costs, Journal of Financial Economics, 92 (3), pp. 443-469. doi:10.1016/j.jfineco.2008.04.010.

21. Leventisa, S. \& Weetmanb, P. (2004). Timeliness of Financial Reporting: Applicability of Disclosure Theories in an Emerging Capital Market, Accounting and Business Research, 1, pp. 43-56. doi:10.1080/00014788.2004.9729950.

22. Mahmoodabadi, H., Rezaei, G. \& Gorgani Firozjah, A. (2014). Examining the Impact of Intellectual Capital on Improving Financial Reporting Quality of the Companies Listed in Tehran Stock Exchange, Journal of Accounting Advances, 5 (2), pp. 75-99. Available at: http://jaa.shirazu.ac.ir/article_1878_379.html.

23. Modarres, A. \& Hesarzadeh, R. (2008). Financial Reporting Quality and Investment Efficiency, Quarterly Journal of Securities Exchange, 1 (2), pp. 85-116. Available at: http://journal.seo.ir/page/article-frame.html?articleId=229.

24. Tehrani, R. \& Noorbakhsh, A. (2006). Investment Management. Tehran: Negahe Danesh Press.

25. Verdi, R. (2006). Financial Reporting Quality and Investment Efficiency. Unpublished PhD Dissertation, Faculties of the University of Pennsylvania in Partial Fulfillment, oR Working Paper. doi:10.2139/ssrn.930922

26. Verrecchia, R. (2001). Essays on Disclosure, Journal of Accounting and Economics, 32 (1-3), pp. 97-180. doi:10.1016/S0165-4101(01)00025-8. 